\title{
Unusual retention of two flatus tubes inserted for sigmoid volvulus
}

\author{
Alexander Photiou, Roland Fernandes, Mohanraj Harlingham \\ Colorectal Department, OEOM Hospital, Kent, UK
}

Correspondence to Roland Fernandes, rfernandes@doctors.org.uk

\section{DESCRIPTION}

A 87-year-old gentleman presented as an acute admission with abdominal distension and inability to open his bowels for the preceding 4 days. His co-morbidities included Down's syndrome, moderate learning disabilities, osteoarthritis and hypertension. He was known to suffer from recurrent sigmoid volvulus which was extensively investigated. Colonoscopy did not reveal any intraluminal pathology and CT scan was unremarkable except for a large, floppy sigmoid colon. Due to his age and co-morbidities it was deemed that he would not be a candidate for sigmoid colectomy. On this admission abdominal radiograph confirmed the presence of a sigmoid volvulus. Bloods including electrolytes were normal. A rectal tube was inserted to decompress the volvulus and connected to a catheter bag for drainage. Both flatus and stool were seen to be passing into the bag during the procedure. When the patient was reviewed the following morning the catheter bag was

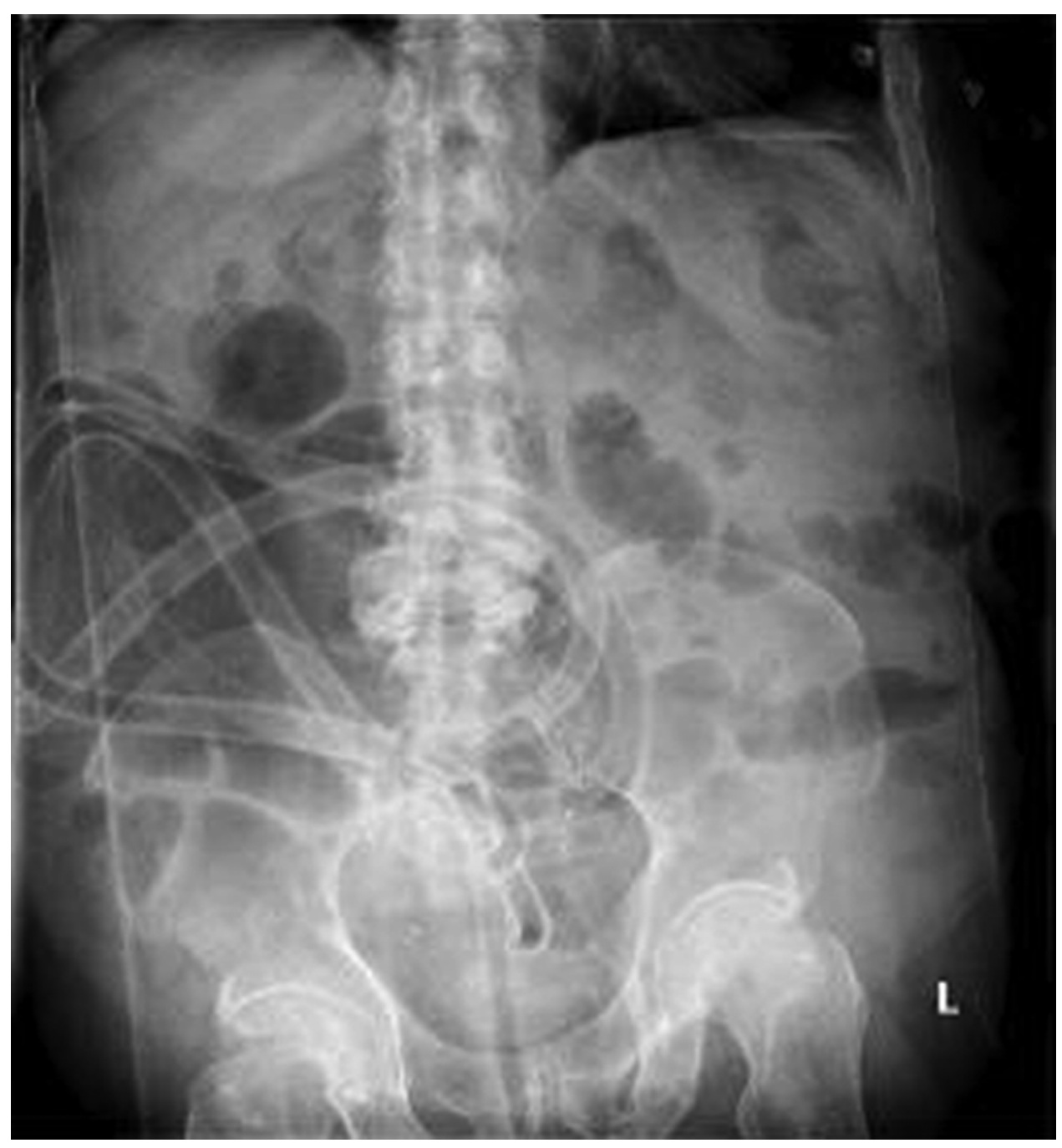

Figure 1 Abdominal radiograph demonstrating two flatus tubes within a sigmoid volvulus. 


\section{BMJ Case Reports}

disconnected and rectal tube was not visible. The abdominal distension had recurred. Rigid sigmoidoscopy was then performed and as no tube was visible, another rectal tube was inserted. When the patient was reviewed later that day the second flatus tube was no longer visible and no resolution of the distension had taken place. Abdominal radiograph revealed two flatus tubes insitu, neither of which were accessible via rigid sigmoidoscopy (figure 1). An urgent flexible sigmoidoscopy was performed and both tubes removed successfully without complication. Although the volvulus was decompressed during the procedure, the patient went on to develop recurrent episodes of volvulus.

\section{Learning points}

- Flatus tubes should be supervised closely, and appropriate documentation was made to record their position and the contents they drain.

- If in any doubt, an abdominal radiograph should be used to determine whether the flatus tube is insitu.

- A flatus tube need only be inserted $15-20 \mathrm{~cm}$ in length.

\section{Competing interests None.}

Patient consent Obtained.

This pdf has been created automatically from the final edited text and images.

Copyright 2012 BMJ Publishing Group. All rights reserved. For permission to reuse any of this content visit http://group.bmj.com/group/rights-licensing/permissions.

BMJ Case Report Fellows may re-use this article for personal use and teaching without any further permission.

Please cite this article as follows (you will need to access the article online to obtain the date of publication).

Photiou A, Fernandes R, Harlingham M. Unusual retention of two flatus tubes inserted for sigmoid volvulus. BMJ Case Reports 2012; 10.1136/bcr.01.2012.5509, Published XXX

Become a Fellow of BMJ Case Reports today and you can:

- Submit as many cases as you like

- Enjoy fast sympathetic peer review and rapid publication of accepted articles

- Access all the published articles

- Re-use any of the published material for personal use and teaching without further permission

For information on Institutional Fellowships contact consortiasales@bmjgroup.com

Visit casereports.bmj.com for more articles like this and to become a Fellow

Keep up to date with all published cases by signing up for an alert (all we need is your email address) http://casereports.bmj.com/cgi/alerts/etoc 